\title{
Subjective perceptions of ESP (English for Specific Purposes) university teachers' professional beginnings: Quantitative research into pedagogical content knowledge
}

\author{
Jana Jašková \\ Masaryk University in Brno, Czech Republic \\ jaskova.jana@gmail.com
}

\begin{abstract}
The aim of this paper is to present methodology and results of a quantitative phase within a research into English for Specific Purposes university teachers and their subjectively perceived changes in pedagogical content knowledge from a retrospective view of their professional beginnings. The introduction describes the investigated issues and explains key concepts. The first chapter refers to the theoretical background of teacher professional development. Since the quantitative research phase is a part of a mixed research design, the second chapter deals with the whole research including the research objective and questions. The third chapter is devoted to the quantitative research phase during which an anonymous electronic questionnaire was sent to the whole population of Czech university teachers of English for Specific Purposes and processed statistically as well as descriptively. The fourth chapter presents the obtained quantitative data discussed within the individual components of pedagogical content knowledge - conceptions of purposes for teaching subject matter, curricular knowledge, knowledge of instructional strategies, and knowledge of students' understanding. The conclusion summarises all the information and proposes some recommendations for pedagogical practice.
\end{abstract}

Keywords

pedagogical content knowledge, English for specific purposes, ESP, professional growth, beginning teacher, university teacher

\section{Introduction}

This paper presents a quantitative research phase carried out within a mixed research investigating changes in university teachers' pedagogical content knowledge from their retrospective view of the first three years of teaching English for Specific Purposes. Currently, English for Specific Purposes (ESP) is the most frequently taught foreign language at Czech universities. Unlike English for General Purposes (EGP) aiming at a broad base of knowledge and skills, ESP is focused on specific professional contexts in respective areas of expertise (Far, 2008, p. 3-4). The basic approach in teaching ESP lies in its adaptation to students' specific needs (Harding, 2007, p. 10-11) - while EGP emphasizes all four language skills (speaking, writing, listening, and reading), in ESP the teacher has to analyze which of these skills students need most for their work (Fiorito, 2005, p. 1). The professional content is another specific feature of ESP which (according to one of many classifications) consists of English for Science and Technology, English for Business and Economics, and English for Social Sciences (Hutchinson \& Waters, 1987, p. 16-17).

In the Czech Republic, ESP university teachers are likely to go through a rather difficult period during the first years of their practice because during their university studies they were prepared for teaching EGP at secondary schools. Therefore, this research is specifically aimed at novices. Based on the fact that the period of novice teachers is usually defined between one and five years of practice (Juklová, 2013, p. 98; Palmer et al., 2005, p. 23; Remmik, Karm, \& Lepp, 2013, p. 332; Steffy et al., 2000, p. 6; Šimoník, 1994, p. 9; Veenman, 1984, p. 143), the concept of ESP university novices has been 
introduced including all teachers during the first three years of teaching ESP at universities, regardless of their possible previous EGP teaching practice at other types of schools.

Pedagogical content knowledge (PCK) is one of the basic categories of teachers' knowledge described as a "special amalgam of content and pedagogy" (Shulman, 1987, p. 8). It represents the knowledge of "the most regularly taught topics in one's subject area, the most useful forms of representation of those ideas, the most powerful analogies, illustrations, examples, explanations and demonstrations", which means that it refers to "the ways of representing and formulating the subject that make it comprehensible to others" (Shulman, 1986, p. 9). The issue of Czech ESP university novices' PCK is rather complicated - the teachers should be able to connect only EGP knowledge with general didactics knowledge. However, their previous education has not provided them with ESP knowledge, university didactics knowledge, and the knowledge of students' branch of study (e.g. medicine, engineering, law). The issue of ESP university novices' PCK is presented in Figure 1.

\section{Theoretical background}

Since the research focuses on changes in ESP university teachers' PCK during the first three years of practice, the following teacher professional development models have been taken into consideration. Firstly, it is necessary to mention models concentrated on pedagogical-didactic approach and based mainly on findings from didactics, pedagogy and cognitive psychology (Píšová et al., 2011, p. 79- 87). In this area, Berliner' model (1995, p. 47-48) seems to be the best known one. It presents teachers' professional development in a linear direction (novice, advanced beginner, competent, proficient and expert levels) but does not take into consideration the influence of individual differences or contextual variables. Other models define three phases in teacher professional development - the primary orientation on the teacher's "survival" in the classroom, the following focus on teaching situations and the final emphasis on students' learning (Fuller, 1969, p. 210-213; Kagan, 1992, p. 156; Maynard \& Furlong, 1995, p. 12-13; Richardson \& Placier, 2001 in Píšová et al., 2011, p. 82-83). In addition to that, some authors insert a phase of initial idealism before the phase of "survival" (Maynard \& Furlong, 1995, p. 12-13; Ryan, 1986, p. 8).

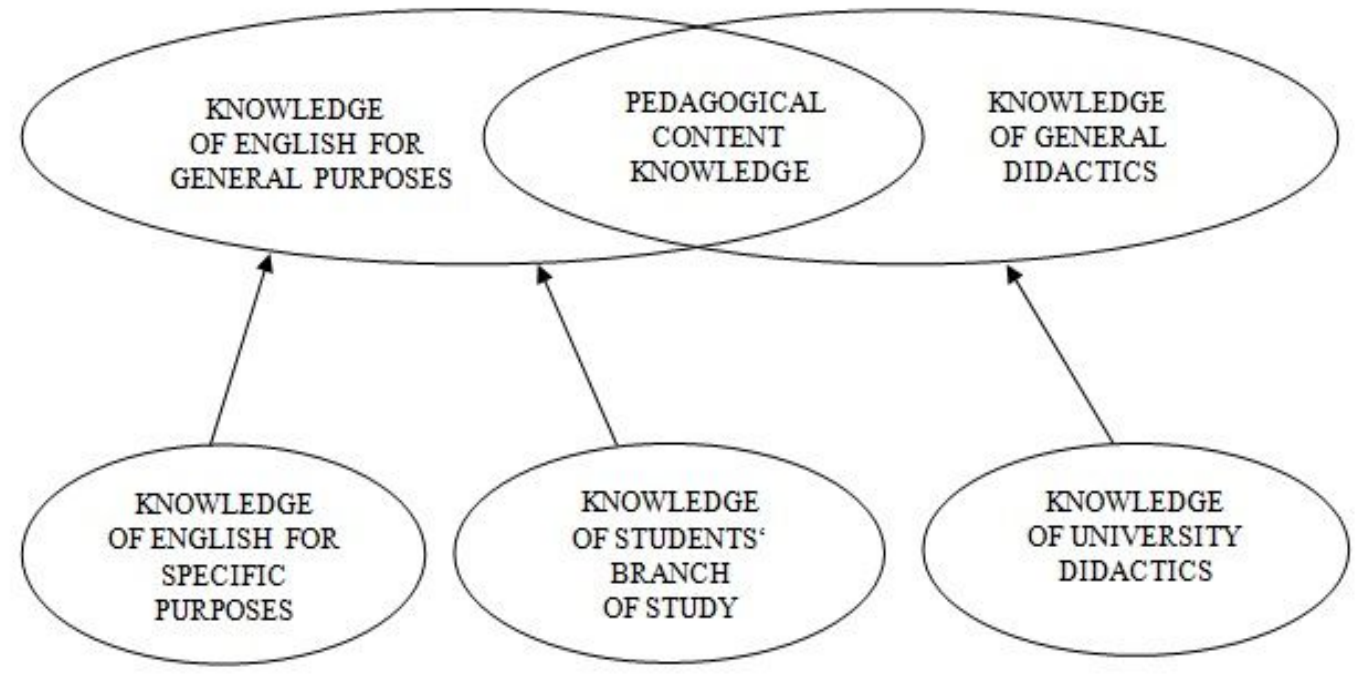

Figure 1: The pedagogical content knowledge of English for Specific Purposes university novices

Secondly, the socio-pedagogical approach to the teacher professional development should be taken into account (Píšová et al., 2011, p. 79-87). From this perspective, Huberman's model is probably the 
most frequently cited one (Glatthorn, 1995, p. 42). It describes the teacher professional development in a linear way with regard to the individual periods of teaching experience (1-3 years, 4-6 years, 7-18 years, 19-30 years, 31-40 years). It is also possible to mention other models dealing with teacher development in relation to the research findings usage (Bevan, 2004, p. 328-336) or to the perception of surroundings (Joyce \& Showers, 2002, p. 148-154). Furthermore, some models are focused on the teacher professional self-image in relation to the influence of external factors (Nias, 1989, p. 66-73; Day et al., 2007, p. 69-70) while others are based on reflection as a professional growth mechanism (Spilková, 2011, p. 120-121; Steffy et al., 2000, p. 6-14).

Thirdly, the socio-pedagogical-didactic approach represents a broader conception based on the above two approaches to the teacher professional development (Píšová et al., 2011, p. 79-87). In this context, it is essential to mention Fessler's model of teacher professional cycle (Fessler \& Ingram, 2003, p. 588) including three interacting subsystems - the career cycle (pedagogical subsystem), the personal environment (psychological subsystem) and the organizational environment (social subsystem). Another global view of the issue is presented in Shulman and Shulman's model (Shulman \& Shulman, 2004 , p. 260-268) where reflection is in the centre of professional development consisting of three levels - individual, community and policy. Finally, Guskey's cyclical model of teacher change (Guskey, 2002, p. 383-386) describes the teacher professional development influencing teaching practice, which affects students' learning outcomes, which results in changes of teachers' beliefs and attitudes, and the entire process is repeated.

During their professional development, the teachers undergo professional learning processes that can be described by several theories. From a cognitive perspective, Anderson's ACT model (Anderson, 1983, p. 1-44) emphasizes learning based on experience and assumes that this process includes three types of memory - short term, declarative and procedural. The transfer of processes from conscious declarative memory to unconscious procedural memory is realised in three stages - cognitive, associative and autonomous (Randall \& Thornton, 2001, p. 30-32). On the other hand, some models emphasize the role of reflection in the process of learning based on experience. It is necessary to mention Korthagen's ALACT model (Korthagen et al., 2001, p. 32-50) consisting of a spiral of the following phases - an action, looking back on the action, awareness of essential aspects, creating alternative methods of action, a trial (a new action) etc. Similarly, Shulman (1987, p. 14-19) mentions reflection in his model of pedagogical reasoning and action describing the professional learning process from a broader perspective - comprehension, transformation (preparation, representation, selection, adaption and tailoring to student characteristics), instruction, evaluation, reflection, new comprehensions etc.

\section{Methodology of the whole mixed research}

As already mentioned, the objective of this paper is to describe the methodology and results of the quantitative research phase. However, this phase is just one part of the whole mixed research. Therefore, it is also essential to deal with the methodology of the whole research whose aim is to investigate subjectively perceived changes in university teachers' PCK from their retrospective view of the first three years of teaching ESP.

The whole research should answer the following question: Did the university teachers perceive any changes in PCK from their retrospective view of the first three years of teaching ESP? If yes, what changes did they perceive? This relatively elaborated research question has been divided into several sub-questions according to Grossman's model of PCK (Grossman, 1990, p. 5-9) where PCK consist of the following individual components: (a) the conceptions of purposes for teaching subject matter (the knowledge and beliefs about the aims of teaching particular topics) - Did the university teachers perceive any changes in their conceptions of objectives for teaching ESP? If yes, what changes did they perceive? (b) the curricular knowledge (the knowledge of curriculum organization and materials available for teaching) - Did the university teachers perceive any changes in their knowledge of curriculum organization and materials for ESP? If yes, what changes did they perceive? (c) the knowledge of 
instructional strategies (the knowledge of strategies and representations for teaching particular topics) Did the university teachers perceive any changes in their knowledge of instructional strategies and representations for ESP? If yes, what changes did they perceive? (d) the knowledge of students' understanding (the knowledge of students' conceptions and misconceptions of particular topics) - Did the university teachers perceive any changes in their knowledge of students' conceptions and misconceptions of ESP? If yes, what changes did they perceive?

The mixed methods research design has been chosen on the grounds of its benefits from the complementarity of qualitative and quantitative approaches (Bergman, 2011, p. 272). During this sequential research design, the results of the first, qualitative phase were essential for the second, quantitative phase confirming and specifying the obtained qualitative data (Hendl, 2008, p. 279). The mentioned combination of approaches has been further supported by the triangulation of data collection methods (Švaříček \& Šed'ová, 2007, p. 204). Since it was not possible to conduct the research for the whole period of three years, the selection of methods has been limited to introspective and retrospective ones - an interview and a questionnaire. During the qualitative phase, individual semistructured interviews on the topic of the first three years of teaching ESP at universities were carried out with 14 respondents - 12 experienced teachers (having three and more years of practice in teaching ESP at universities) and 2 novice teachers (having less than three years of this practice). The obtained data were analysed by thematic coding and the results were used in the following quantitative phase where anonymous electronic questionnaires were sent to the whole population of Czech ESP university teachers and completed by 98 respondents - 86 experienced teachers and 12 novice teachers. Subsequently, the quantitative data were processed statistically as well as descriptively.

Since the methodology and results of the first, qualitative research phase have been presented in another paper (Jašková, 2015), the following text deals entirely with the second, quantitative phase of the whole research.

\section{Methodology of the quantitative research phase}

The quantitative research phase consisted of three parts - a pilot study, a preliminary research, and a main research (Gavora, 2012, p. 48-49). The pilot study investigated whether the questionnaire was comprehensible by a personal contact with 3 respondents. During the preliminary research, the electronic questionnaire was sent to 20 respondents and completed by 15 of them. Finally, the questionnaire was sent to the whole population of electronically accessible Czech ESP university teachers (712 respondents) and completed by 83 of them. Therefore, altogether 98 completed questionnaires from the preliminary as well as main research have been obtained, which corresponds to the required number of respondents for questionnaire surveys (Gavora, 2000, p. 67; Kohoutek, 1998, p. 10).

\subsection{Questionnaire content and structure}

Since it was necessary to meet the requirement of maximum 15 -minute limit of completing electronic questionnaires (Gavora, 2000, p. 107), only some data obtained in the previous qualitative research phase could be included in it. Therefore, twenty following sub-categories have been chosen from the categorial system consisting of five main categories: (a) the factographic information (eight sub-categories) - the period of the first three years of teaching ESP at universities, the length of the whole practice in teaching ESP at universities, the length of potential preceding practice in English teaching, the length of potential preceding practice in university teaching, the respondent's university qualifications, the respondent's educational qualifications, ESP specialization during the first three years, ESP level during the first three years; (b) the conceptions of purposes for teaching subject matter (three sub-categories) - the educational objectives within the area of ESP, the educational objectives outside the area of ESP, the pedagogical objectives; (c) the curricular knowledge (three sub-categories) - the syllabus for teaching ESP, the materials for teaching ESP, the professional content of ESP; (d) the knowledge of instructional strategies (three sub-categories) - the ways of motivating students, the 
organizational forms of teaching, the strategies to cope with the professional content; (e) the knowledge of students' understanding (three sub-categories) - students' effective approaches to learning, students' learning styles and strategies, students' acquired knowledge and skills.

On the basis of the above sub-categories, twenty questions have been formulated for the questionnaire. Four of the questions were open and sixteen questions were semi-closed (Pelikán, 2011, p. 107-108). The open questions corresponded to the first four sub-categories of the factographic information where respondents entered a specific number of years. The remaining semi-closed questions offered various answers as well as the possibility of writing one's own answer. Moreover, next to each offered answer there were other items forming four columns in order to map the changes during the first three years: (a) yes, only at the beginning of the first three years; (b) yes, only at the end of the first three years; (c) yes, at the beginning as well as the end of the first three years; (d) no, neither at the beginning nor at the end of the first three years. For illustration, one question from the questionnaire can be found in Figure 2.

\subsection{Data analysis}

The analysis of the obtained data has been conducted at three levels: (a) PCK-component-level - the statistical analysis within the individual PCK components where each component consists of three questions, (b) question-level - the statistical analysis within the individual questions from the questionnaire where each question consists of several answers, (c) answer-level - the descriptive analysis within the individual answers from the questionnaire. While the statistical analysis was focused on the differences between realized and unrealized changes during the first three years as well as on the changes between the beginning and the end of the period, the descriptive analysis was concentrated only on the latter. It is also to be noted that the data from 12 novice teachers were processed in isolation from 86 experienced teachers and used for validation.

During the analysis, the respondents were counted up in each of the four columns (see Chapter 3.1) at the level of answers, questions and PCK components. The pairs of sums were compared within the beginning and the end of the first three years (columns (a) $x$ (b)) and the realized and unrealized changes during this period (columns $(a+b) \times(c+d)$ ). Pearson's chi-squared test verified whether the obtained frequencies differed from the theoretical frequencies assuming there was no difference between the observed phenomena (Chráska, 2007, p. 71-72). The results at the expected frequency of $50 \%$ were compared with the critical value of test criterion (3.841) for the degree of freedom 1 and the level of significance 0.05 . Chi-square results higher than the critical value were considered to be significant. 
9. Which ESP objectives did you consider most important?

Select one option in each line

\begin{tabular}{|c|c|c|c|c|}
\hline & $\begin{array}{l}\text { YES - onily at } \\
\text { the beginning of } \\
\text { the first } 3 \text { years }\end{array}$ & $\begin{array}{l}\text { YES - only at } \\
\text { the end of the } \\
\text { first } 3 \text { years }\end{array}$ & $\begin{array}{l}\text { YES - at the } \\
\text { beginning as } \\
\text { well as the end } \\
\text { of the first } 3 \\
\text { years }\end{array}$ & $\begin{array}{l}\text { NO-neither at } \\
\text { the beginning } \\
\text { nor at the end of } \\
\text { the first } 3 \text { years }\end{array}$ \\
\hline $\begin{array}{l}\text { pronumciation } \\
\text { development }\end{array}$ & a & $=$ & $=$ & - \\
\hline $\begin{array}{l}\text { vocabulary } \\
\text { development }\end{array}$ & $a$ & $=$ & $=$ & $=$ \\
\hline $\begin{array}{l}\text { grammar } \\
\text { development }\end{array}$ & - & $=$ & $=$ & $=$ \\
\hline $\begin{array}{l}\text { listening skill } \\
\text { development }\end{array}$ & 0 & - & $=$ & $=$ \\
\hline $\begin{array}{l}\text { reading skill } \\
\text { development }\end{array}$ & 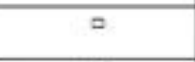 & a & - & $=$ \\
\hline $\begin{array}{l}\text { speaking skill } \\
\text { development }\end{array}$ & $=$ & $a$ & = & $=$ \\
\hline $\begin{array}{l}\text { writing skill } \\
\text { development }\end{array}$ & - & $=$ & $=$ & $=$ \\
\hline $\begin{array}{l}\text { all the above } \\
\text { mentioned items } \\
\text { were equally } \\
\text { important }\end{array}$ & $=$ & $=$ & $=$ & - \\
\hline $\begin{array}{l}\text { I had no ESP } \\
\text { objectives }\end{array}$ & $=$ & a & $=$ & - \\
\hline
\end{tabular}

Others:

You can supply your own answer (a few words)

Figure 2: The illustration of one question from the questionnaire

\subsection{Research sample}

As mentioned above, altogether 98 questionnaires have been completed by 12 novice teachers (having less than three years of ESP teaching experience) and 86 experienced teachers (having three and more years of this experience). The following text deals with the factographic information obtained from all the respondents.

The period of the first three years of teaching ESP at universities. The respondents started teaching ESP at universities 1-35 years (10.2 years on average) before completing the questionnaire, i.e. during the period 1980-2014.

The length of the whole practice in teaching ESP at universities. The length of the ESP university teachers' practice was 1-30 years (9.6 years on average) before completing the questionnaire, which indicates some respondents' interruption in teaching ESP (compared with the information in the previous paragraph).

The length of potential preceding practice in English teaching. Before teaching ESP at universities, the teachers had been teaching English language at various types of schools for 0-29 years (5.7 years on average).

The length of potential preceding practice in university teaching. Before teaching ESP at universities, the teachers had been teaching any other subjects at universities for 0-15 years (1.1 years on average).

The respondent's university qualifications. At the beginning of teaching ESP at universities, $92 \%$ of respondents had had their academic degree in English (and $82 \%$ also in another subject). During the first three years, additional $3 \%$ of teachers completed their studies of English (and $4 \%$ of another subject).

The respondent's educational qualifications. At the beginning of teaching ESP at universities, 89 $\%$ of respondents had had some pedagogical qualifications and additional $4 \%$ of teachers acquired this competence during the first three years. 
ESP specialization during the first three years. The respondents differed a lot in the professional content of ESP which was technical (40-35) ${ }^{1}$, business (39-35), social (30-31), natural (16-14) and medical (13). It is clear from the figures that during the first three years some teachers were teaching more than one specialization.

ESP level during the first three years. The level of ESP was A1 (14-11), A2 (32-23), B1 (63-57), B2 (60-62), C1 (27-30) and C2 (5) according to Common European Framework of Reference for Languages (2001). Although B1 and B2 were the prevailing levels for the whole period, the above figures suggest a tendency of increasing ESP level during the first three years.

\section{Results and discussion}

In accordance with the objective of this paper, the following text presents only data obtained in the quantitative research phase. As mentioned above, the emphasis is placed on information provided by experienced teachers while data from novices are used for validation.

The statistical analysis aimed at realised and unrealized changes during the first three years shows the statistical significance of unrealised changes in all PCK components, which means that most experienced teachers did not perceive any changes during the period. Nevertheless, they might not have realised or remembered the changes in their retrospective view of the distant past. However, this argument would be in conflict with the data obtained from novice teachers who were in the period of the first three years and thus had everything in recent memory. This group of respondents has also proved the statistical significance of unrealised changes, even if their chi-square values are noticeably lower. In other words, the university teachers did not perceive any statistically significant changes in PCK from their retrospective view of the first three years of teaching ESP. Pearson's chi-squared test values concerning the differences between realised and unrealized changes are presented in Table 1.

Table 1: Pearson's chi-squared test values concerning the differences between realised and unrealized changes during the first three years $\left(^{*}=\right.$ the number of unrealized changes is significantly higher than the number of realised changes)

\begin{tabular}{|l|c|c|}
\hline \multirow{2}{*}{$\begin{array}{c}\text { PCK-component-level } \\
\text { Question-level }\end{array}$} & $\begin{array}{c}\text { Chi-square values } \\
\text { Novice teachers } \\
\text { teachers }\end{array}$ & \\
\hline Conceptions of purposes for teaching subject matter & $1371.803^{*}$ & $48.016^{*}$ \\
\hline - Educational objectives within the area of ESP & $566.207^{*}$ & $16.333^{*}$ \\
- Educational objectives outside the area of ESP & $388.961^{*}$ & $9.389^{*}$ \\
- Pedagogical objectives & $417.240^{*}$ & $24.500^{*}$ \\
\hline Curricular knowledge & $1146.056^{*}$ & $50.417^{*}$ \\
\hline - Syllabus for teaching ESP & $156.465^{*}$ & $6.750^{*}$ \\
- Materials for teaching ESP & $382.724^{*}$ & $23.048^{*}$ \\
- Professional content of ESP & $618.687^{*}$ & $21.333^{*}$ \\
\hline Knowledge of instructional strategies & $1251.469^{*}$ & $43.860^{*}$ \\
\hline - Ways of motivating students & $551.535^{*}$ & $24.000^{*}$ \\
- Organizational forms of teaching & $314.940^{*}$ & 1.067 \\
- Strategies to cope with the professional content & $385.496^{*}$ & $26.889^{*}$ \\
\hline Knowledge of students' understanding & $1520.304^{*}$ & $54.545^{*}$ \\
\hline - Students' effective approaches to learning & $584.238^{*}$ & $26.042^{*}$ \\
- Students' learning styles and strategies & $392.442^{*}$ & $10.889^{*}$ \\
- Students' acquired knowledge and skills & $544.395^{*}$ & $18.375^{*}$ \\
\hline
\end{tabular}

${ }^{1}$ The numbers in brackets represent the number of teachers at the beginning and at the end of the first three years. 
Table 2: Pearson's chi-squared test values concerning the differences between the beginning and the end of the first three years $*^{*}=$ the number of items at the end is significantly higher than at the beginning, ${ }^{* *}=$ the number of items at the beginning is significantly higher than at the end)

\begin{tabular}{|l|c|c|}
\hline PCK-component-level & \multicolumn{2}{|c|}{ Chi-square values } \\
\cline { 2 - 3 } $\begin{array}{l}\text { Question-level } \\
\text { Conceptions of purposes for teaching subject } \\
\text { matter }\end{array}$ & $25.138^{*}$ & Novice teachers \\
\hline - Educational objectives within the area of ESP & $4.571^{*}$ & $59.507^{* *}$ \\
- Educational objectives outside the area of ESP & $19.882^{*}$ & $33.000^{* *}$ \\
- Pedagogical objectives & $5.538^{*}$ & $12.565^{* *}$ \\
\hline Curricular knowledge & 2.051 & $15.000^{* *}$ \\
\hline - Syllabus for teaching ESP & 0.000 & $33.985^{* *}$ \\
- Materials for teaching ESP & 1.984 & $5.400^{* *}$ \\
- Professional content of ESP & 1.195 & $7.200^{* *}$ \\
\hline Knowledge of instructional strategies & $4.745^{*}$ & $22.533^{* *}$ \\
\hline - Ways of motivating students & $18.778^{*}$ & $52.563^{* *}$ \\
- Organizational forms of teaching & 0.032 & $16.667^{* *}$ \\
- Strategies to cope with the professional content & 0.714 & $22.154^{* *}$ \\
\hline Knowledge of students' understanding & 1.469 & $14.000^{* *}$ \\
\hline - Students' effective approaches to learning & 0.037 & $40.500^{* *}$ \\
- Students' learning styles and strategies & 0.758 & $12.565^{* *}$ \\
- Students' acquired knowledge and skills & 0.947 & $8.909^{* *}$ \\
\hline
\end{tabular}

\subsection{Conceptions of purposes for teaching subject matter}

It is evident from Table 2 that there is a statistically significant increase in the number of objectives at the end of the first three years within the PCK component relating to the conceptions of purposes for teaching subject matter. This statistical significance has also been proved at the level of all three questions concerning the educational objectives within the area of ESP, educational objectives outside the area of ESP and pedagogical objectives. To sum up, the university teachers perceived statistically significant changes in the objectives from their retrospective view of the first three years of teaching ESP, which could indicate their professional development. Specific differences between the beginning and the end of the period at the answer-level from the descriptive analysis are discussed in the following text.

Educational objectives within the area of ESP. The emphasis on grammar and vocabulary development was monitored at the beginning of the period while at the end there was a prevailing emphasis on writing, reading, speaking, and listening skill development. Therefore, there seems to be a transition from the primary focus on language means to the final focus on language skills. From the perspective of communicative competence, which is the main goal of foreign language teaching, the respondents transferred their attention from students' language competence towards their pragmatic competence (Bagaric \& Djigunovič, 2007, p. 99-100).

Educational objectives outside the area of ESP. The respondents emphasised learning autonomy and critical thinking development of students. As this emphasis was concentrated on the end of the first three years, it could be assumed that their professional development was gradual. During the period, the teachers apparently realized the importance of students' learning autonomy and critical thinking which are integral parts of tertiary education (Ramsden, 1992, p. 96-103; Vašutová, 2002, p. 58) while the former is also a characteristic feature of post-communicative approach in foreign language teaching (Dakowska, 2011, p. 82; Janíková, 2011, p. 58). 
Pedagogical objectives. During the first three years, the teachers were gradually stressing the development of students' moral attitudes, intercultural tolerance, responsible approach to study, and decent behaviour during lessons. Therefore, the respondents were progressively developing many teaching objectives, which is in accordance with literature referring to novices' professional development (Berliner, 1995, p. 47-48).

\subsection{Curricular knowledge}

It is obvious from Table 2 that there are no statistically significant changes between the beginning and the end of the first three years in the area of PCK component aimed at curricular knowledge. No statistical significance has also been found at the level of questions concerning the syllabus for teaching ESP, the materials for teaching ESP, and the professional content of ESP. Therefore, the university teachers did not perceive any statistically significant changes in the knowledge of curriculum from their retrospective view of the first three years of teaching ESP. However, on the basis of the descriptive analysis some differences between the beginning and the end of the period have been noticed and are presented in the following text.

Syllabus for teaching ESP. At the beginning of the first three years, most respondents had prepared and established syllabi. At the end of the period, the teachers either took part in syllabi production or created their own syllabi, which suggests their professional development. Thus, they became curriculum authors in the onthodidactic transformation of content - they had to choose curricular contents from branch contents, in which they were not educated, and incorporate them into the curriculum (Janik, Manak, \& Knecht, 2009, p. 39).

Materials for teaching ESP. It has been noticed that the teachers initially used prepared and complete materials, while at the end they either took part in collective production of teaching materials or prepared their own ESP materials. Besides, the respondents used mainly Czech textbooks at the beginning while at the end of the first three years they emphasised textbooks from English publishers. Above all, during the period they also created an increasing number of supplementary materials, which might make their professional development evident.

Professional content of ESP. At the beginning, the respondents acquired their knowledge of ESP professional content primarily through discussions with other ESP teachers, while at the end they relied on professional publications, textbooks or internet materials, and on courses, lectures or seminars. Therefore, the teachers lacking specific ESP education seem to become gradually familiar with this professional content by means of the above devices, which could indicate their professional growth.

\subsection{Knowledge of instructional strategies}

As Table 2 shows, some statistically significant changes have been observed at the level of PCK component dealing with the knowledge of instructional strategies. However, within the question-level statistical analysis this significance has been remarked only in the area of the ways of motivating students, while no significance has been found in the sphere of the organizational forms of teaching and the strategies to cope with the professional content. To conclude, the university teachers perceived some statistically significant changes in the knowledge of instructional strategies from their retrospective view of the first three years of teaching ESP, which could indicate their professional development. Specific differences between the beginning and the end of the period from the descriptive analysis within the answer-level are introduced in the following text.

Ways of motivating students. It has been found out that at the end of the period the respondents emphasised primarily useful teaching connected with practice, thus following the latest trends in ESP teaching (Harding, 2007, p. 10-11) and adult education (Barták, 2008, p. 27-31). Moreover, the teachers gradually preferred amusing teaching with interesting activities and considered students' active participation during their final assessment. This combination of intrinsic and extrinsic motivation is considered to be an effective way of encouraging students' active participation in learning processes (Cangelosi, 2014, p. 137). 
Organizational forms of teaching. In general, the respondents applied frontal teaching at the beginning and pair or group teaching at the end of their initial practice (Gavora, 2005, p. 117-121). This trend is considered to be very effective, unlike the traditional teacher's main role in the classroom preventing students' development of activity, independence and creativity (Maňák, 1998, p. 106). To sum up, the teachers were initially concentrated on their own survival, particularly on establishing their roles in the classroom management (Maynard \& Furlong, 1995, p. 12-13), then their professional confidence began to increase and they focused attention on students' learning processes (Richardson \& Placier, 2001, in Píšová et al., 2011, p. 82-83).

Strategies to cope with the professional content. At the beginning of their practice, the respondents did not solve problems concerning the professional content themselves. Instead, they referred students to experts in the field. Less often, they asked students for explanation or tried to solve the problem themselves. At the end of the period, the teachers asked students for dealing with the problem or let them teach the professional content. Therefore, it can be assumed that the ESP university teachers shifted their responsibility for the professional content towards their students. To conclude, the novices' teaching strategies developed progressively in connection with their experience acquisition (van Driel, Verloop, \& de Vos, 1998, p. 681-682).

\subsection{Knowledge of students' understanding}

It is clear from Table 2 that there is no statistical significance both at the PCK-component-level related to the knowledge of students' understanding and at the question-level concerning students' effective approaches to learning, students' learning styles and strategies, and students' acquired knowledge and skills. Therefore, the university teachers did not perceive any statistically significant changes in the knowledge of students' conceptions from their retrospective view of the first three years of teaching ESP. However, at the level of descriptive analysis some evident changes have been found and are presented in the following text.

Students' effective approaches to learning. At the beginning of the first three years, the respondents emphasised regular grammar and vocabulary exercises as the best way of learning ESP. From the perspective of foreign language acquisition, the focus on language means is rooted in behaviourism (Lightbown \& Spada, 2006, p. 34) and the accent on repetition is based on cognitivism (Cook, 2001, p. 189). At the end of the period, the teachers preferred practising of speaking, writing and reading skills. The focus on productive language skills can be associated with social interactionism (Mitchell \& Myles, 2004, p. 195-196), while the emphasis on receptive language skills has its roots in nativism (VanPatten \& Williams, 2007, p. 30-32). Moreover, the above mentioned shift from language means to language skills validates the previous findings within the category of purposes for teaching subject matter.

Students' learning styles and strategies. It has been found out that the teachers gradually focused their attention on students' learning styles and strategies by discussing this topic with them or by monitoring their responses during lessons. It is evident that the novices started to be interested in students' learning processes (Fuller, 1969, p. 210-213; Kagan, 1992, p. 156) and act in accordance with their learning styles (Steffy et al., 2000, p. 6-10).

Students' acquired knowledge and skills. To find out and evaluate students' knowledge and skills, the respondents initially emphasised regular homework in accordance with the idea that adult people should be responsible for satisfying their own educational needs (Mužík, 2004, p. 26). At the end of the period, they preferred oral seminar work (e.g. presentations), written seminar work (e.g. essays) and continuous oral examinations. Therefore, the teachers started to pay attention to students' independent creative activities reflecting the latest trends in tertiary education (Vašutová, 2002, p. 54).

\section{Conclusion}

At Czech universities, ESP is usually taught by teachers whose university education has been focused on teaching EGP at secondary schools. Because of this non-specific undergraduate preparation, ESP 
university teachers can be short of basic kinds of knowledge forming their PCK, such as the knowledge of ESP, the knowledge of students' branch of study, and the knowledge of university didactics. For this reason, they may meet many difficulties during their initial practice. This idea has led to the attempt to investigate their situation during the first three years of working experience.

A mixed design has been used for the whole research examining ESP university teachers' subjectively perceived changes in PCK from a retrospective point of view. The first, qualitative phase consisted of semistructured interviews conducted with several ESP university teachers and analysed by thematic coding. This paper presents the second, quantitative phase during which the data were collected with the aid of electronic questionnaires sent to the whole population of Czech ESP university teachers and analyzed statistically as well as descriptively.

The quantitative results show that statistically significant changes between the beginning and the end of the period have been found in two PCK components - the conceptions of purposes for teaching subject matter and the knowledge of instructional strategies. The remaining two PCK components - the curricular knowledge and the knowledge of students' understanding - have not shown any statistically significant changes. However, in terms of descriptive analysis many changes have been noticed in all PCK components, which could indicate the teachers' professional growth during the first three years of their career.

The research should contribute to the expansion of scientific theories dealing with PCK in relation to the period when EGP secondary school teachers were becoming ESP university teachers. From a practical viewpoint, the research could help to inform the professional community about ESP university novices' demanding situation caused by their non-specifically targeted education. This way, the research might be an impulse for introducing changes in the university preparation of future ESP teachers and for supporting these teachers during the first years of their practice.

\section{References}

ANDERSON, J. R. (1983). The architecture of cognition. Cambridge, MA: Harward University Press.

BAGARIČ, V., \& DJIGUNOVIČ, J. M. (2007). Defining communicative competence. Metodika, 8(1), 94-103.

BARTÁK, J. (2008). Jak vzdělávat dospělé [How to educate adults]. Praha: Alfa Nakladatelství.

BERGMAN, M. M. (2011). The good, the bad, and the ugly in mixed methods research and design. Journal of Mixed Methods Research, 5(4), 271-275.

BERLINER, D. C. (1995). Teacher expertise. In L.W. Anderson (Ed.), International encyclopedia of teaching and teacher education (p. 46-52). Oxford: Elsevier Science Ltd.

BEVAN, R. M. (2004). Filtering, fragmenting, and fiddling? Teachers' life cycles, and phases in their engagement with research. Teacher Development, 8(2), 325-339.

CANGELOSI, J. S. (2014). Classroom management strategies: Gaining and maintaining students' cooperation. Hoboken, NJ: John Wiley \& Sons.

CHRÁSKA, M. (2007). Metody pedagogického výzkumu: Základy kvantitativního výzkumu [Methods of pedagogical research: Fundamentals of quantitative research]. Praha: Grada.

Common European framework of reference for languages: Learning, teaching, assessment (2001). Cambridge: Cambridge University Press. Available at: http://www.coe.int/t/dg4/education/elp/elpreg/Source/Key_reference/CEFR_EN.pdf

COOK, V. (2001). Second language learning and language teaching. $3^{\text {rd }}$ edition. London: Hodder Arnold.

DAKOWSKA, M. (2011). Teaching English as a foreign language. Warsawa: Wydavnictwo naukowe PWN.

DAY, CH., SAMMONS, P., STOBART, G., KINGTON, A., \& QUING, G. (2007). Teachers matter: Connecting lives, work and effectiveness. Maidenhead: McGraw Hill.

FAR, M. M. (2008). On the relationship between ESP \& EGP: A general perspective. English for Specific Purposes World, 7(1), 1-11.

FESSLER, R., \& INGRAM, R. (2003). The teacher career cycle revisited: New realities, new responses. In Davies, B. \& West-Burnham, J. (Eds.), Handbook of educational leadership and management (s. 584590). Edinburgh: Pearson Education Limited. 
FIORITO, L. (2005). Teaching English for Specific Purposes. Available from http://www.usingenglish.com/teachers/articles/teaching-english-for-specific-purposes-esp.html

FULLER, F. F. (1969). Concerns of teachers: A developmental conceptualization. American Educational Research Journal, 6(2), 207-226.

GAVORA, P. (2000). Úvod do pedagogického výzkumu [Introduction to pedagogical research]. Brno: Paido.

GAVORA, P. (2005). Učitel a žáci v komunikaci [Teacher and students in communication]. Brno: Paido.

GAVORA, P. (2012). Tvorba výskumného nástroja pre pedagogické bádanie [Creating research tool for pedagogical research]. Bratislava: Slovenské pedagogické nakladatel'stvo.

GLATTHORN, A. (1995). Teacher development. In Anderson, L. W. (Ed.), International encyclopedia of teaching and teacher education (s. 41-46). Oxford: Elsevier Science Ltd.

GROSSMAN, P. L. (1990). The making of a teacher: Teacher knowledge and teacher education. New York: Teachers College Press.

GUSKEY, T. R. (2002). Professional development and teacher change. Teachers and Teaching: Theory and Practice, 8(3/4), 381-391.

HARDING, K. (2007). English for Specific Purposes. Oxford: Oxford University Press.

HENDL, J. (2008). Kvalitativní výzkum: Základní teorie, metody a aplikace [Qualitative research: Basic theories, methods and applications]. Praha: Portál.

HUTCHINSON, T., \& WATERS, A. (1987). English for Specific Purposes: A learning-centred approach. Cambridge: Cambridge University Press.

JANÍK, T., MAŇÁK, J., \& KNECHT, P. (2009). Cíle a obsahy školního vzdělávání a metodologie jejich utvárení [Objectives and contents of school education and methodology of their formation]. Brno: Paido.

JANÍKOVÁ, V. (2011). Výuka cizích jazyků zaměřená na žáka [Foreign language teaching focused on student]. In Janíková, V. a kol. (Ed.), Výuka cizích jazyků [Foreign language teaching] (p. 50-77). Praha: Grada.

JAŠKOVÁ, J. (2015, in print). Subjektivní percepce profesních počátků vysokoškolských učitelů odborné angličtiny: Kvalitativní výzkum didaktických znalostí obsahu [Subjective perceptions of English for Specific Purposes university teachers' professional beginnings: Qualitative research into pedagogical content knowledge]. Pedagogická orientace, 25(5), 700-721.

JOYCE, B., \& SHOVERS, B. (2002). Student achievement through staff development (3rd ed.). Alexandria, VA USA: ASCD.

JUKLOVÁ, K. (2013). Začínající učitel z pohledu profesního vývoje [Beginning teacher from the perspective of professional development]. Hradec Králové: Gaudeamus.

KAGAN, D. M. (1992). Professional growth among preservice and beginning teachers. Review of Educational Research, 62(2), 129-169.

KOHOUTEK, R. (1998). Metoda dotazníku pro pedagogy [Method of questionnaire for pedagogues]. Brno: CERM.

KORTHAGEN, F. KESSELS, J., KOSTER, B., LAGERWERF, B., \& WUBBELS, T. (2001). Linking practice and theory: The pedagogy of realistic teacher education. Mahwah, NJ: Lawrence Erlbaum Associates.

LIGHTBOWN, P. M., \& SPADA, N. (2006). How languages are learned. Oxford: Oxford University Press.

MAŇÁK, J. (1998). Rozvoj aktivity, samostatnosti a tvořivosti žákủ [Development of pupils' activity, independence and creativity]. Brno: Masarykova univerzita.

MAYNARD, T., \& FURLONG, J. (1995). Learning to teach and models of mentoring. In Kelly, T. \& Mayes, A. S. (Eds.), Issues in mentoring (p. 10-30). London: Routledge.

MITCHELL, R., \& MYLES, F. (2004). Second language learning theories. $2^{\text {nd }}$ edition. London: Hodder Arnold.

MUŽÍK, J. (2004). Androdidaktika [Androdidactics]. Praha: ASPI.

NIAS, J. (1989). Primary teachers talking: A study of teaching as work. London: Routledge. 
PALMER, D. J., STOUGH, L. M., BURDENSKI, T. K., \& GONZALES, M. (2005). Identifying teacher expertise: An examination of researchers' decision making. Educational Psychologist 40(1), 13-25.

PELIKÁN, J. (2011). Základy empirického výzkumu pedagogických jevů [Basics of empirical research of pedagogical phenomena]. Praha: Karolinum.

PÍŠOVÁ, M., NAJVAR, P., JANÍK, T., HANUŠOVÁ, S., KOSTKOVÁ, K., JANÍKOVÁ, V., ... ZERZOVÁ, J. (2011). Teorie a výzkum expertnosti $v$ učitelské profesi [Theory and research of experts in teacher profession]. Brno: Masarykova univerzita.

RAMSDEN, P. (1992). Learning to teach in higher education. London: Routledge.

RANDALL, M., \& THORNTON, B. (2001). Advising and supporting teachers. Cambridge: Cambridge University Press.

REMMIK, M., KARM, M., \& LEPP, L. (2013). Learning and developing as a university teacher: Narratives of early career academics in Estonia. European Educational Research Journal, 12(3), 330-341.

RYAN, K. (1986). The induction of new teachers. Bloomington, Ind.: Phi Delta Kappa Educational Foundation.

SHULMAN, L. S. (1986). Those who understand: Knowledge growth in teaching. Educational Researcher, 15(2), 4-14.

SHULMAN, L. S. (1987). Knowledge and teaching: Foundations of the new reform. Harvard Educational Review, 57(1), 1-22.

SHULMAN, L. S., \& SHULMAN, J. H. (2004). How and what teachers learn: A shifting perspective. Journal of Curriculum Studies, 36(2), 257-271.

SPILKOVÁ, V. (2011). Development of student teachers' professional identity through constructivist approaches and self-reflective techniques. Orbis Scholae, 5(2), 117-138.

STEFFY, B. E., WOLFE, M. P., PASCH, S. H., \& ENZ, B. J. (Eds.). (2000). Life cycle of the career teacher. Thousand Oaks: Corwin Press.

ŠIMONÍK, O. (1994). Začínající učitel: Některé pedagogické problémy začínajících učitelü [Beginning teacher: Some pedagogical problems of beginning teachers]. Brno: Masarykova univerzita.

ŠVAŘÍČEK, R., \& ŠEĎOVÁ, K. (2007). Kvalitativní výzkum v pedagogických vědách: Pravidla hry [Qualitative research in pedagogical sciences: Rules of the game]. Praha: Portál.

Van DRIEL, J. H., VERLOOP, N., \& De VOS, W. (1998). Developing science teacher's pedagogical content knowledge. Journal of Research in Science Teaching, 35(6), 673-695.

VanPATTEN, B., \& WILLIAMS, J. (2007). Early theories in second language acquisition. In VanPatten, B. \& Williams, J. (Eds.), Theories in second language acquisition: An introduction (p. 17-35). Mahwah: Lawrence Erlbaum Associates.

VAŠUTOVÁ, J. (2002). Strategie výuky ve vysokoškolském vzdělávání [Teaching strategies in university education]. Praha: Pedagogická fakulta UK.

VEENMAN, S. (1984). Perceived problems of beginning teachers. Review of Educational Research, 54(2), 143-178.

\section{Contact}

Mgr. Jana Jašková

Masaryk University, Faculty of Education

Institute for Research in School Education

Poříčí 31a, 60300 Brno, Czech Republic

jaskova.jana@gmail.com 